\title{
Does balneotherapy provide additive effects to physical therapy in patients with subacute supraspinatus tendinopathy? A randomized, controlled, single-blind study
}

\author{
Cihan $\operatorname{Koç}^{1}$ (D) Emine Eda Kurt ${ }^{2} \cdot$ Fatmanur Aybala Koçak $^{2} \cdot$ Hatice Rana Erdem ${ }^{2} \cdot$ Naime Meriç Konar $^{2}$
}

Received: 13 July 2020 / Revised: 5 October 2020 / Accepted: 8 October 2020 / Published online: 22 October 2020

(C) The Author(s) 2020

\begin{abstract}
This study assessed the additional contribution of balneotherapy on physical therapy in subacute supraspinatus tendinopathy. Ninety patients with subacute supraspinatus tendinopathy were included. They were randomized into two equal groups. In group $1(n=45)$, transcutaneous electrical nerve stimulation (TENS), hot pack, ultrasound treatments, and Codman's and range of motion (ROM) exercises were performed. In group $2(n=45)$, balneotherapy was added to the treatment program. In both groups, shoulder active ROM and handgrip strength were measured. Pain was evaluated using a Visual Analogue Scale (VAS) (rest, sleep, movement); functional assessment and quality of life were measured respectively with the Shortened Disabilities of the Arm, Shoulder and Hand Questionnaire (QuickDASH), and the Short Form-36 health survey (SF 36) form. All measurements were repeated before and after 15 treatment sessions. There were statistically significant differences between the before and after assessment parameters in group 1 (all $p<0.05$ ), but not for SF-36 General Health Perceptions, SF-36 Mental Health sub-parameters, and handgrip strengths. However, there were statistically significant differences between all the evaluation before and after the treatment in group 2 (all $p<0.05$ ). When the two groups were compared in terms of alpha gains, statistically significant differences were observed in favor of group 2 in all measurements (all $p<0.05$ ) except for SF-36 Emotional Role Difficulty and SF-36 Mental Health sub-parameters. This study shows that the addition of balneotherapy to physical therapy for subacute supraspinatus tendinopathy can make additional contributions to shoulder ROM, pain, handgrip strength, functional status, and quality of life.
\end{abstract}

Keywords Subacute supraspinatus tendinopathy $\cdot$ Balneotherapy $\cdot$ Rotator cuff lesions $\cdot$ Physical therapy

\section{Introduction}

The shoulder joint has the greatest range of movement in the body. Shoulder pain is the third most common problem in the general population, after back and neck pain among musculoskeletal system issues (Roe et al. 2013). Its prevalence varies between 7 and $26 \%$. The wide range of prevalence rates has been explained in the literature by the use of different definitions (Luime et al. 2009). Acute shoulder pain is defined as symptoms lasting up to 6 weeks, subacute lasts 6 to 12 weeks, and chronic pain is defined as symptoms lasting longer than 12

Cihan Koç

pinoyoo@hotmail.com

1 Bahçe Physical Therapy and Rehabilitation Hospital, Osmaniye, Turkey

2 Ahi Evran University Faculty of Medicine, Kırşehir, Turkey weeks. Studies indicate that the duration of symptoms is the most important in terms of prognosis. Chronic pain makes treatment difficult and increases treatment costs (Reilingh et al. 2008). Periarticular causes account for up to $90-95 \%$ of shoulder pain. Among these, rotator cuff lesions are the most common cause. Rotator cuff lesions vary in a broad spectrum from tendinitis to partial and complete tears and calcific tendinopathy. Studies using diagnostic imaging methods in shoulder pain showed that rotator cuff pathologies were most frequently observed in the supraspinatus tendon (Vecchio et al. 1995; Karel et al. 2017).

In treatment, conservative methods such as analgesic and anti-inflammatory drugs, various injections, exercises, and physical therapy are used. Various trends and modalities, hot-cold treatments, deep heating agents, mobilization, and manipulation techniques are used in physical therapy. In cases where conservative treatments are inadequate, surgical methods are used (Filiz and Çakır 2014). 
Balneotherapy is frequently used for musculoskeletal diseases including shoulder diseases in our country and some European and Asian countries (Forestier et al. 2017). There are many studies assessing the effects of balneotherapy in hand and knee osteoarthritis, chronic low back pain, and degenerative diseases such as lumbar spondylosis and mechanical neck pain, and in fibromyalgia (Nasermoaddeli and Kagamimori 2005; Fioravanti et al. 2014; Roques and Queneau 2016; Branco et al. 2016).

The additional contribution of balneotherapy to treatment in shoulder pathologies has been investigated in a limited number of studies. However, these studies included patients who were treated with broad definitions such as subacromial impingement syndrome or chronic shoulder pain (Șen et al. 2010; Chary-Valckenhaere et al. 2012). Also, only a few studies indicated the efficacy of balneotherapy in chronic shoulder pain (Șen et al. 2010; Chary-Valckenhaere et al. 2012; Tefner et al. 2015). Only one study showed the beneficial effects of peloid treatment in subacromial impingement syndrome, which is one of the causes of shoulder pain (Șen et al. 2010). The effects of thermal water baths have not been studied adequately in shoulder pathologies.

In light of all these data, the additive effects of balneotherapy on physical therapy in patients with subacute supraspinatus tendinopathy (6-12 weeks) were aimed to investigate. We evaluated health-related quality of life, emotional mood, sleep, pain scores, functional evaluation of the shoulder, handgrip strength, and active range of motion (ROM).

\section{Material and methods}

This single-blind, randomized controlled trial was conducted in the Physical Medicine and Rehabilitation Department Outpatient Clinic of the Ahi Evran University Medical Faculty. Declaration of Helsinki protocols were followed, and local ethics committee approval for the study was obtained (process no: 2018-06/62). The study was performed between March 29, 2019, and April 30, 2019 (ACTRN12619000045112). This study also conforms to all consort guide lines and reports the required information accordingly. The patients were evaluated by a single researcher (CK) both before and after the treatment periods. The researcher was blinded as to which treatment protocol the patients had been ordered.

The G-power (v.3.1.9.2) program was used to determine the sample size, and it was concluded that a minimum of 45 people in each group was required to achieve an effect size of approximately $d=0.5$ (medium-level effect size) at $80 \%$ power and 5\% significance level (Cohen 2013).

Patients between the ages of 20-65 with 6-12 weeks of unilateral shoulder pain were examined. Neer, Hawkins, and painful arc tests are provocative tests for subacromial impingement. All tests were performed to the patients. Patients who were positive in at least one of these three tests were evaluated. To be diagnosed with subacute supraspinatus tendinopathy (Burbank et al. 2008), pain severity (VAS 4 and above) is moderate or severe, full passive range of motion were assigned as inclusion criteria.

Other shoulder evaluation tests (Cools et al. 2008), physical examination, laboratory, and diagnostic imaging were performed. Patients with the differential diagnosis of shoulder pain were excluded and patients with subacute supraspinatus tendinopathy with the affected shoulder MRI were included in the study.

In the Neer test, one hand stabilizes the patient's scapula while the other hand raises the arm into full flexion; a positive test is indicated by pain. The Hawkins test involves flexing the shoulder to $90^{\circ}$ then forcibly internally rotating it, though gentle internal rotation has also been recommended. Pain in the shoulder area indicates that the test is positive. When performing the painful arc test, the patient is asked to actively lift the arm in the scapular plane, then slowly reverse the movement. The test is noted positive if the patient has pain between 60-120 degrees of during elevation (Çaliş et al. 2000). A detailed history was taken from all patients. Musculoskeletal system and neurologic examinations were performed and radiologic (shoulder anteroposterior (AP)/ lateral, cervical AP/lateral), serologic (acute phase reactants, erythrocyte sedimentation rates, C-reactive protein (CRP), rheumatoid factor (RF)), and biochemical analysis (liver function tests, fasting blood glucose (FBG), urea, uric acid, creatinine) and hemograms were obtained. Magnetic resonance (MR) imaging was performed on the affected shoulder in all cases.

The exclusion criteria were specified as follows: shoulder instability; those who underwent shoulder surgery; positive drop arm test; diagnosed adhesive capsulitis; rotator cuff tear; osteonecrosis; cuff arthropathy or arthritis; a history of shoulder injection in the past one year; acromioclavicular joint pathology; those who received physical therapy and/or received therapeutic balneotherapy in the past one year; those with a history of fracture or dislocation in the shoulder area; calcific tendinitis on radiography; neurologic deficit; regional diseases (cervical radiculopathy, brachial neuritis, complex regional pain syndrome, peripheral neuropathy), rheumatologic, oncologic, infectious disease, coagulopathy, and severe cardiovascular and pulmonary disease; patients with visceral-induced shoulder pain; a history of severe psychiatric illness; and breastfeeding or pregnant women.

According to the inclusion and exclusion criteria, 98 patients who were diagnosed as having subacute supraspinatus tendinopathy were included in the study; eight patients dropped out for various reasons (Fig. 1). The study was completed with 90 patients (53 women and 37 men). The participants were given detailed information about the study and their written approval was obtained.

Patients were randomly divided into two equal groups using the covariate adaptive randomization method (variables: 
Fig. 1 Flow diagram of the study population

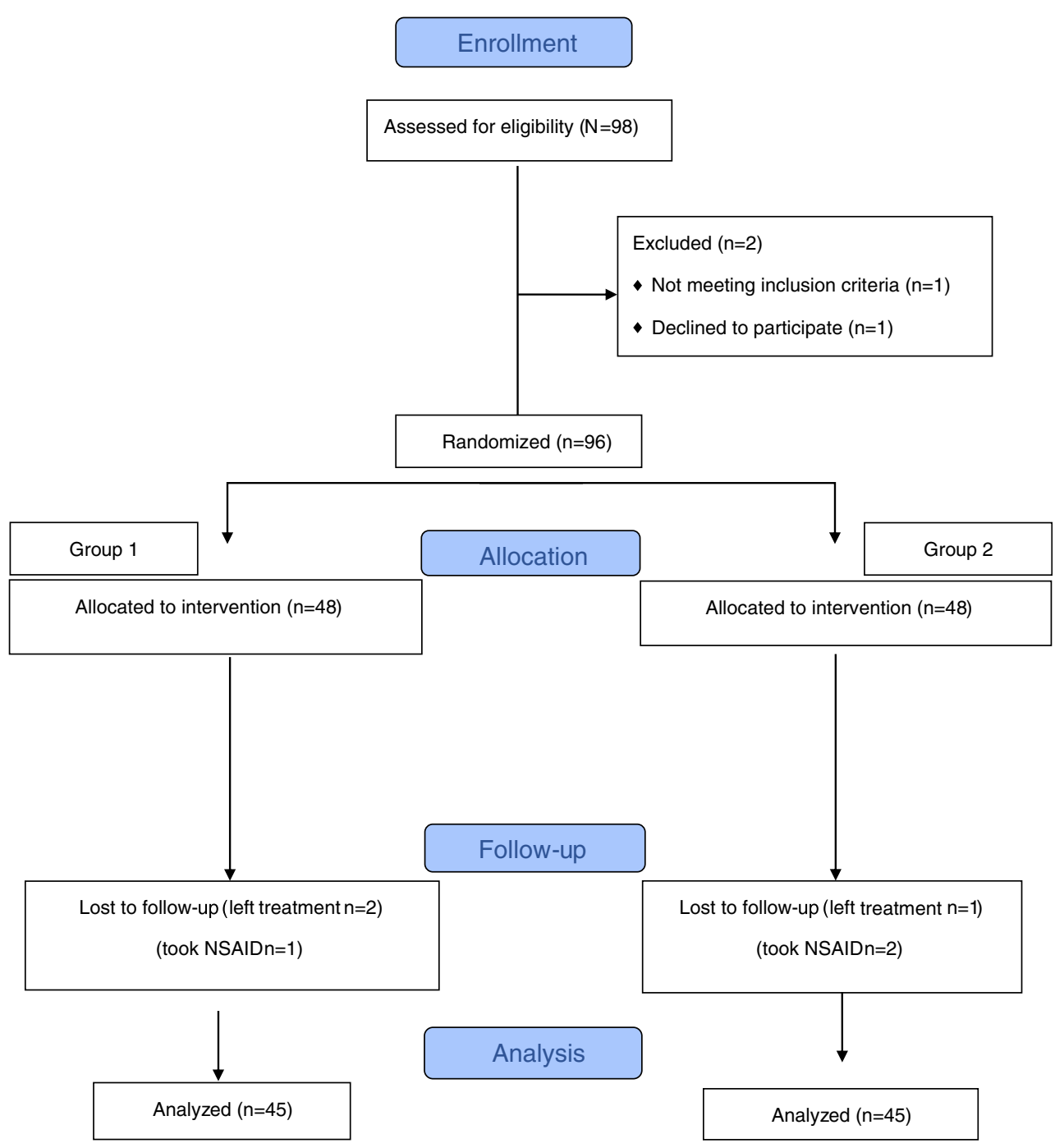

age, sex, education level) with a computer program (Kang et al. 2008).

Group 1 received transcutaneous electrical nerve stimulation (TENS), hot pack, ultrasound (US), and exercise treatment. Group 2 received balneotherapy in addition to the treatments given to group 1. All treatments were performed in a total of 15 sessions; five days per week.

TENS treatment was performed by crossing the electrodes, including the supraspinatus muscle and the aching area, at 60$80 \mathrm{~Hz}$ frequency, $100 \mathrm{msec}$ pulse intervals, with a current intensity at 1 to $100 \mathrm{~mA}$, where the patient feels a slight tingling, without causing contraction. During treatment, the patient's arm was supported with a pillow in a resting position while the patient was sitting. Each session lasted $20 \mathrm{~min}$.

Hot pack treatment was performed by placing a hot pack containing silica gel on the aching shoulder, which was heated in water at $72-75^{\circ} \mathrm{C}$ in a boiler, and wrapped in two layers of towels. The treatment was performed once a day for $20 \mathrm{~min}$.

The US treatment was performed by moving the probe with continuous contact in circular movements over the aching shoulder, at a dose of $1.5 \mathrm{w} / \mathrm{cm}^{2}$ in the continuous mode, for 6 min per day.

For exercises, Codman's pendulum exercises were given to both groups of patients. The exercises were actively performed by the patient under the supervision and directions of the researcher for $15 \mathrm{~min}$.

In group 2, balneotherapy was given at Kırșehir Terme Spas, which operate under the Department of Physical Medicine and Rehabilitation in Ahi Evran University. The hot mineral water at $42 \pm 1{ }^{\circ} \mathrm{C}$ contains $98.3 \mathrm{mg} / \mathrm{L}$ sulfur, $556 \mathrm{mg} / \mathrm{L}$ bicarbonate, $186.7 \mathrm{mg} / \mathrm{L}$ sodium, $34.5 \mathrm{mg} / \mathrm{L}$ magnesium, $226 \mathrm{mg} / \mathrm{L}$ calcium, $232 \mathrm{mg} / \mathrm{L}$ chloride, $2.6 \mathrm{mg} / \mathrm{L}$ fluoride, and $58.43 \mathrm{mg} / \mathrm{L}$ silicate acid. Spa treatment was given to the patients as a whole-body bath and assigned as $20 \mathrm{~min}$.

No analgesic or anti-inflammatory drugs were allowed to be taken during the study. None of the patients were using pregabalin and/or gabapentin.

The demographic and affected shoulders characteristics were recorded. The active ROM (flexion, extension, abduction, internal and external rotation) of the affected shoulder 
was measured using a goniometer. Grip strength evaluations were performed using a Jamar hand dynamometer. The patients were asked to grade their pain during sleep, rest, and movement using a Visual Analogue Scale (VAS) scoring system. A shortened Disabilities of the Arm, Shoulder and Hand Questionnaire (QuickDASH) and the Short Form-36 health survey (SF-36) quality of life scale were administered before and after the study.

The VAS is a scale used for the evaluation of pain severity. The scale is a $10-\mathrm{cm}$ line with the left-most part showing no pain, and the right-most part showing maximum pain. All patients were asked to mark the most appropriate statement on the line according to the pain (Hong 2011). The SF-36 scale is used measure of quality of life, that consists of 36 items evaluating physical functioning; physical role functioning; emotional role functioning; social role functioning; general health, mental health; bodily pain, and vitality. Scores for the eight domains are calculated by summing up the item scores. Each domain is scored from 0 to 100 , with 0 indicating the worst health status and 100 indicating the best health status. The validity and reliability studies of the scale have been performed in the Turkish population (Kocyigit et al. 1999).

QuickDASH is an 11-item questionnaire, that measure physical function and symptoms in patients with upper limb musculoskeletal disorders. The 11 items of QuickDASH handle daily activities, house/garden work, shopping, recreation, self-care, eating, sleep, friends, work, pain, and tingling/ numbness. The validity and reliability studies of the scale have been performed in the Turkish population (Düger et al. 2006).

The SPSS 22.0 (IBM Corp. released 2013; IBM SPSS Statistics for Windows, version 22.0. Armonk, NY: IBM
Corp.) package program was used for all analyses. The normality of measured data distributions was evaluated using the Shapiro-Wilk test. Continuous data are showed as mean \pm standard deviation (SD), and categorical data are presented as percentages (\%). If the data were normally distributed, Student's $t$ test was used, and the Mann-Whitney U test was used if the data were not normally distributed. Qualitative comparisons of the groups were performed using the Chisquare test. Additionally paired $t$ tests were used to compare repeated measures for each group if the data were normally distributed. And the Wilcoxon test was used if the data were not normally distributed. The threshold for statistical significance was set at $p<0.05$.

\section{Results}

There was no statistically significant difference between the treatment groups regarding demographic characteristics such as age, sex, body mass index, and education $(p>0.05)$. Also, there was no significant difference in baseline pain duration in either group $(p>0.05)$ (Table 1).

Positivity-negativity ratios of diagnostic tests such as Neer, Hawkins, and the painful arc test were similar in both treatment groups (all $p>0.05$ ) (Table 2).

In group 1 and group 2, the pre and post-treatment ROM measurements (flexion, extension, internal rotation, and external rotation) were evaluated, and statistical significantly improvements were detected in both groups after the treatments $(p<0.05)$ (Table 3).

Table 1 Demographic characteristics

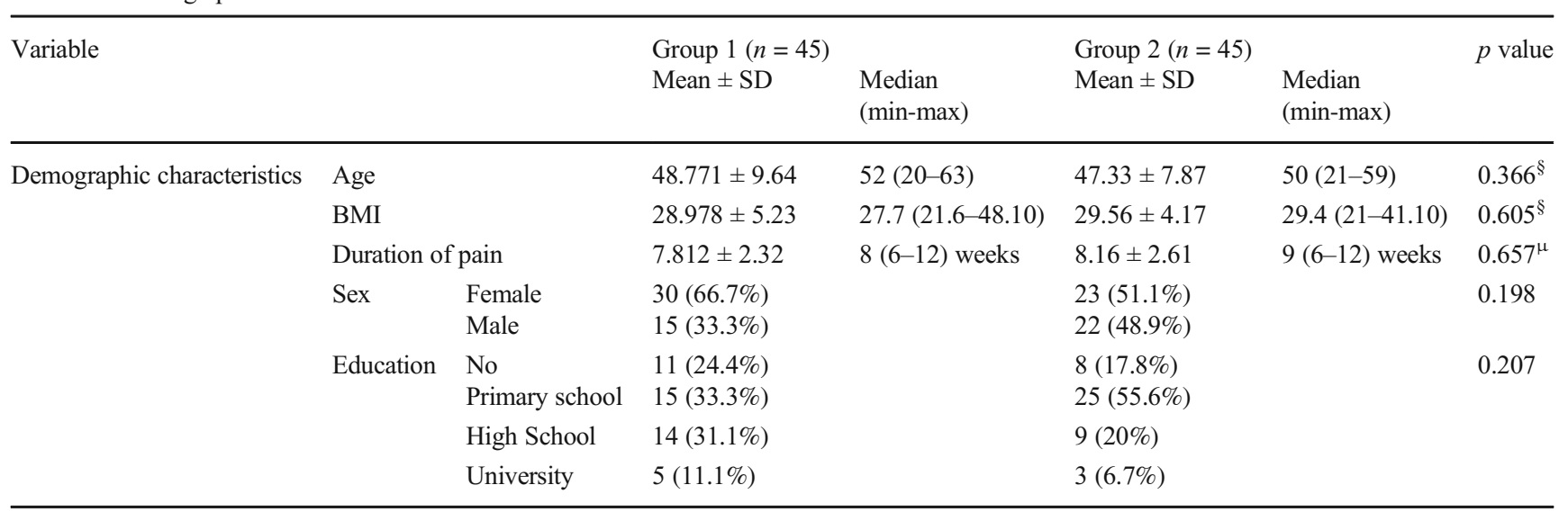

\footnotetext{
$\S_{t}$ test in independent groups
}

${ }^{\mu}$ Mann-Whitney $U$ test

Group 1 patients receiving physical therapy and exercises for treatment

Group 2 patients receiving physical therapy, balneotherapy, and exercises for treatment

$B M I$ body mass index $/ \mathrm{kg} / \mathrm{m}^{2}$ 
Table 2 Special tests used for diagnosis

\begin{tabular}{lllll}
\hline Special tests & & Group 1 $(n=45)$ & Group 2 $(n=45)$ & $p$ value \\
\hline \multirow{2}{*}{ Neer } & Positive & $35(77.8 \%)$ & $36(80 \%)$ & 0.999 \\
& Negative & $10(22.2 \%)$ & $9(20 \%)$ & \\
Hawkins & Positive & $19(42.2 \%)$ & $18(40 \%)$ & 0.999 \\
& Negative & $26(57.8 \%)$ & $27(60 \%)$ & \\
\multirow{2}{*}{ Painful arc } & Positive & $40(88.9 \%)$ & $41(91.1 \%)$ & 0.999 \\
& Negative & $5(11.1 \%)$ & $4(8.9 \%)$ & \\
& Negative & $30(66.7 \%)$ & $30(66.7 \%)$ & \\
\hline
\end{tabular}

Group 1 patients receiving physical therapy and exercises for treatment Group 2 patients receiving physical therapy, balneotherapy, and exercises for treatment

Additionally, both groups were improved significantly with respect to VAS values (resting, sleep, movement), and QuickDASH scores after the treatments (Table 4) ( $p$ $<0.05$ ).

In the post-treatment Jamar hand dynamometer measurements in group 1, there was no significant difference compared with the pre-treatment measurements $(p>0.05)$. However, the post-treatment measurements of the Jamar hand dynamometer were detected significantly higher than the pretreatment measurements in group $2(p<0.05)$ (Table 4$)$.

In group 1, there were no significant differences between measurements of before and after treatment related with SF 36 General Health, and SF 36 Mental Health values (all $p>0.05$ ). Group 2 statistically significant improvements were found in all other sub-parameters $(p<0.05)$. However, there were significant improvements in the post-treatment values in all parameters of SF-36 compared with pre-treatment in group $2(p$ $<0.05$ ) (Table 5).
The difference between the treatment efficacy of the two groups was evaluated using delta gains. There was no significant difference between the two groups regarding SF-36 Emotional and SF36 Mental Health gains $(p>0.05)$. In terms of the delta gains of all other variables, a statistically significant difference was found in favor of group $2(p<0.05)$ (Table 6).

\section{Discussion}

In our study, a significant improvement was observed in active ROM measurements, QuickDASH, and VAS (during rest, sleep, movement) scores in both groups $(p<0.05)$. However, the difference in the group receiving additional balneotherapy was significantly higher than in the other group $(p<0.05)$. Similar to our results, in the study of Şen et al. (2010), peloid treatment, which is a method of balneotherapy, provided an increase in shoulder ROM measurements, shoulder function, and a significant improvement in VAS scores. In a multicenter study in which the effectiveness of balneotherapy in shoulder pain associated with chronic cuff tendinopathy was evaluated, a significant improvement was observed in the DASH scores of the group receiving the spa treatment (Chary-Valckenhaere et al. 2012). Although similar results were obtained in the study of Tefner et al. (2015), in which thermal water and balneotherapy was used in patients with chronic shoulder pain, as in our study, no significant difference was found between the groups' ROM measurements. This result was considered to be caused by the capsular tension and adhesions associated with chronic pathologies of the patients included in the study.

Table 3 Comparison of pre- and post-treatment range of motion in groups 1 and 2

\begin{tabular}{|c|c|c|c|c|c|c|}
\hline \multirow[t]{2}{*}{ Group } & \multirow[t]{2}{*}{ ROM } & \multicolumn{2}{|l|}{ Pre-treatment } & \multicolumn{2}{|l|}{ Post-treatment } & \multirow[t]{2}{*}{$p$ value } \\
\hline & & Mean \pm SD & $\begin{array}{l}\text { Median } \\
\text { (min-max) }\end{array}$ & Mean \pm SD & $\begin{array}{l}\text { Median } \\
\text { (min-max) }\end{array}$ & \\
\hline \multirow[t]{4}{*}{ Group 1} & Flexion & $169.56 \pm 18.82$ & $180(100-180)$ & $176.22 \pm 8.06$ & $180(150-180)$ & $0.001^{\top}$ \\
\hline & Abduction & $168.22 \pm 21.88$ & $180(90-180)$ & $174.56 \pm 11.96$ & $180(120-180)$ & $0.001^{\Upsilon}$ \\
\hline & Internal rotation & $83.78 \pm 12.30$ & $90(40-90)$ & $87.67 \pm 6.87$ & $90(50-90)$ & $0.007^{\Upsilon}$ \\
\hline & External rotation & $72.33 \pm 21.34$ & $80(10-90)$ & $78.78 \pm 18.56$ & $90(20-90)$ & $<0.001^{\top}$ \\
\hline \multirow[t]{4}{*}{ Group 2} & Flexion & $162.67 \pm 20.38$ & $180(100-180)$ & $176.11 \pm 12.10$ & $180(110-180)$ & $<0.001^{\top}$ \\
\hline & Abduction & $158.89 \pm 25.69$ & $170(90-180)$ & $174.56 \pm 18.02$ & $180(80-180)$ & $<0.001^{\top}$ \\
\hline & Internal rotation & $75.78 \pm 18.40$ & $90(30-90)$ & $87.56 \pm 6.10$ & $90(60-90)$ & $<0.001^{\top}$ \\
\hline & External rotation & $66.11 \pm 20.22$ & $70(10-90)$ & $81.22 \pm 11.78$ & $90(50-90)$ & $<0.001^{\top}$ \\
\hline
\end{tabular}

\footnotetext{
${ }^{\top}$ Wilcoxon test
}

Group 1 patients receiving physical therapy and exercises for treatment

Group 2 patients receiving physical therapy, balneotherapy, and exercises for treatment

$R O M$ range of motion 
Table 4 Comparison of pre- and post-treatment VAS, QuickDASH, and Jamar measurements in groups 1 and 2

\begin{tabular}{|c|c|c|c|c|c|c|}
\hline \multirow[t]{2}{*}{ Group } & & \multicolumn{2}{|l|}{ Pre-treatment } & \multicolumn{2}{|l|}{ Post-treatment } & \multirow[t]{2}{*}{$p$ value } \\
\hline & & Mean \pm SD & $\begin{array}{l}\text { Median } \\
(\min -\max )\end{array}$ & Mean \pm SD & $\begin{array}{l}\text { Median } \\
\text { (min-max) }\end{array}$ & \\
\hline \multirow[t]{5}{*}{ Group1 } & Resting VAS & $2.78 \pm 2.60$ & $2(0-8)$ & $1.78 \pm 2.28$ & $0(0-8)$ & $<0.001^{\Upsilon}$ \\
\hline & Sleep VAS & $7.49 \pm 1.78$ & $8(5-10)$ & $4.67 \pm 2.88$ & $5(0-10)$ & $<0.001^{\mathrm{P}}$ \\
\hline & Movement VAS & $6.95 \pm 2.50$ & $7(0-10)$ & $4.47 \pm 2.63$ & $5(0-10)$ & $<0.001^{\pi}$ \\
\hline & QuickDASH & $42.34 \pm 19.85$ & $40(6.8-88.6)$ & $27.61 \pm 20.14$ & $25(2.2-86.3)$ & $<0.001^{\pi}$ \\
\hline & Handgrip strength (Jamar) & $24 \pm 10.04$ & $23(8-48)$ & $23.82 \pm 11.87$ & $24(9-50)$ & $0.142^{\pi}$ \\
\hline \multirow[t]{5}{*}{ Group2 } & Resting VAS & $3.11 \pm 2.69$ & $3(0-8)$ & $0.93 \pm 1.37$ & $0(0-5)$ & $<0.001^{\Upsilon}$ \\
\hline & Sleep VAS & $8.2 \pm 1.89$ & $8(4-10)$ & $4.22 \pm 2.70$ & $4(0-10)$ & $<0.001^{\Upsilon}$ \\
\hline & Movement VAS & $7.6 \pm 2.31$ & $7.5(0-10)$ & $4.04 \pm 2.64$ & $4(0-10)$ & $<0.001^{\Upsilon}$ \\
\hline & QuickDASH & $43.84 \pm 21.95$ & $40.45(6.8-88.6)$ & $19.44 \pm 16.48$ & $13.6(2.2-65.9)$ & $<0.001^{\top}$ \\
\hline & Handgrip strength (Jamar) & $24.71 \pm 10.07$ & $22(4-58)$ & $26.47 \pm 12.05$ & $24(10-60)$ & $<0.001^{\top}$ \\
\hline
\end{tabular}

${ }^{\pi}$ Paired $t$ test

${ }^{\top}$ Wilcoxon test

Group 1 patients receiving physical therapy and exercises for treatment

Group 2 patients receiving physical therapy, balneotherapy, and exercises for treatment

$V A S$ Visual Analogue Scale

QuickDASH Quick Disabilities of the Arm, Shoulder and Hand

Table 5 Comparison of pre- and post-treatment SF-36 assessment in groups 1 and 2

\begin{tabular}{|c|c|c|c|c|c|c|}
\hline \multirow[t]{2}{*}{ Group } & & \multicolumn{2}{|l|}{ Pre-treatment } & \multicolumn{2}{|l|}{ Post-treatment } & \multirow[t]{2}{*}{$p$ value } \\
\hline & & Mean \pm SD & Median (min-max) & Mean \pm SD & Median (min-max) & \\
\hline \multirow[t]{8}{*}{ Group 1} & SF36 Vitality & $55.11 \pm 21.83$ & $55(5-95)$ & $57.44 \pm 21.26$ & $55(20-95)$ & $0.012^{\Upsilon}$ \\
\hline & SF36 Physical Function & $60.04 \pm 23.52$ & $72.2(11.1-100)$ & $69.59 \pm 25.1$ & $72.2(11-100)$ & $<0.001^{\top}$ \\
\hline & SF36 Pain & $39.39 \pm 23.53$ & $42.5(0-90)$ & $62.39 \pm 26.62$ & $67.5(0-100)$ & $<0.001^{\pi}$ \\
\hline & SF36 General Health Perception & $47.89 \pm 24.20$ & $50(0-100)$ & $48.44 \pm 23.42$ & $50(0-90)$ & $0.498^{\pi}$ \\
\hline & SF36 Physical Role Limitation & $25.22 \pm 41.52$ & $0(0-100)$ & $45 \pm 45.73$ & $25(0-100)$ & $0.002^{\Upsilon}$ \\
\hline & SF36 Emotional Role Limitation & $65.92 \pm 46.32$ & $100(0-100)$ & $75.55 \pm 41.07$ & $100(0-100)$ & $0.018^{\varphi}$ \\
\hline & SF36 Social Function & $80.56 \pm 27.25$ & $100(0-100)$ & $85.28 \pm 21.03$ & $100(37.5-100)$ & $0.024^{\Upsilon}$ \\
\hline & SF36 Mental Health & $64.10 \pm 18.12$ & $64(20-96)$ & $65.22 \pm 18.5$ & $68(20-96)$ & $0.136^{\Upsilon}$ \\
\hline \multirow[t]{8}{*}{ Group 2} & SF36 Vitality & $52.56 \pm 23.64$ & $50(5-95)$ & $66.78 \pm 20.15$ & $75(25-90)$ & $<0.001^{\top}$ \\
\hline & SF36 Physical Function & $57.24 \pm 27.65$ & $61.1(5.6-100)$ & $77.63 \pm 20.71$ & $83.3(22.2-100)$ & $<0.0011^{\pi}$ \\
\hline & SF36 Pain & $33.28 \pm 21.92$ & $35(0-90)$ & $67.89 \pm 25.28$ & $77.5(0-100)$ & $<0.001^{\top}$ \\
\hline & SF36 General Health Perception & $47.56 \pm 26.15$ & $50(0-100)$ & $54.33 \pm 22.85$ & $55(10-100)$ & $<0.001^{\pi}$ \\
\hline & SF36 Physical Role Limitation & $29.44 \pm 41.73$ & $0(0-100)$ & $70 \pm 42.51$ & $100(0-100)$ & $<0.001^{\top}$ \\
\hline & SF36 Emotional Role Limitation & $61.48 \pm 48.70$ & $100(0-100)$ & $88.89 \pm 31.78$ & $100(0-100)$ & $<0.001^{\top}$ \\
\hline & SF36 Social Function & $77.78 \pm 30.84$ & $100(0-100)$ & $95.56 \pm 10.37$ & $100(50-100)$ & $<0.001^{\top}$ \\
\hline & SF36 Mental Health & $56.53 \pm 21.48$ & $62(8-96)$ & $68.10 \pm 1610$ & $72(28-88)$ & $<0.001^{\top}$ \\
\hline
\end{tabular}

\footnotetext{
${ }^{\pi}$ Paired $t$ test
}

${ }^{\top}$ Wilcoxon test

Group 1 patients receiving physical therapy and exercises for treatment

Group 2 patients receiving physical therapy, balneotherapy, and exercises for treatment

SF36 Short Form-36 
Table 6 Comparison of $\Delta$ (post-treatment-pre-treatment) gains per group

Treatment group

$p$ value

\begin{tabular}{lllll}
\hline Group 1 & & Group 2 & \\
\cline { 1 - 1 } Mean \pm SD & $\begin{array}{l}\text { Median } \\
(\text { min-max })\end{array}$ & & Mean \pm SD & $\begin{array}{l}\text { Median } \\
(\text { min-max })\end{array}$
\end{tabular}

\begin{tabular}{|c|c|c|c|c|c|}
\hline Flexion & $6.67 \pm 15.37$ & $0(-10,70)$ & $13.44 \pm 17.57$ & $10(0-70)$ & $0.021^{\mu}$ \\
\hline Abduction & $6.33 \pm 12.99$ & $0(-10,60)$ & $15.67 \pm 21.73$ & $10(-10,80)$ & $0.018^{\mu}$ \\
\hline Internal rotation & $3.10 \pm 10.05$ & $0(0-50)$ & $11.78 \pm 17.62$ & $0(-20,60)$ & $0.008^{\mu}$ \\
\hline External rotation & $6.44 \pm 10.20$ & $0(-20,40)$ & $15.11 \pm 16.74$ & $10(-20,70)$ & $0.01^{\mu}$ \\
\hline Resting VAS & $-1 \pm 1.58$ & $0(-6,1)$ & $-2.18 \pm 2.15$ & $-2(-6,0)$ & $0.008^{\mu}$ \\
\hline Sleep VAS & $-2.82 \pm 2.50$ & $-2(-10,0)$ & $-3.98 \pm 2.70$ & $-4(-10,0)$ & $0.034^{\mu}$ \\
\hline Movement VAS & $-2.50 \pm 2.46$ & $-2(-9,2)$ & $-3.56 \pm 2.29$ & $-4(-10,0)$ & $0.028^{\mu}$ \\
\hline QuickDASH & $-14.73 \pm 13.16$ & $-11.4(-51,3.7)$ & $-24.4 \pm 17.84$ & $-15.9(-75,-2.2)$ & $0.007^{\mu}$ \\
\hline SF36 Vitality & $2.33 \pm 9.80$ & $0(-45,20)$ & $14.22 \pm 21.56$ & $5(-20,65)$ & $0.028^{\mu}$ \\
\hline SF36 Physical Function & $9.55 \pm 10.92$ & $11.1(-11.1,44.4)$ & $20.38 \pm 18.95$ & $16.6(0,61.1)$ & $0.001^{\S}$ \\
\hline SF36 Pain & $23 \pm 23.79$ & $22.5(-42.5,67.5)$ & $34.61 \pm 23.85$ & $32.5(0,90)$ & $0.043^{\mu}$ \\
\hline SF36 General Health & $0.51 \pm 5.46$ & $0(-15,15)$ & $6.78 \pm 18.16$ & $0(-30,65)$ & $0.026^{\mu}$ \\
\hline SF36 Physical Role Limitation & $19.78 \pm 37.69$ & $0(-50,100)$ & $40.56 \pm 47.76$ & $25(-100,100)$ & $0.01^{\mu}$ \\
\hline SF36 Emotional Role Limitation & $9.63 \pm 25.25$ & $0(0,100)$ & $27.41 \pm 44.54$ & $0(0-100)$ & $0.068^{\mu}$ \\
\hline SF36 Social Function & $4.72 \pm 14.42$ & $0(-12.5,75)$ & $17.78 \pm 25.35$ & $0(0-75)$ & $0.003^{\mu}$ \\
\hline SF36 Mental Health & $1.13 \pm 10.06$ & $0(-35,24)$ & $11.56 \pm 19.22$ & $0(-8,60)$ & $0.081^{\mu}$ \\
\hline Hand grip strength (Jamar) & $0.71 \pm 3.19$ & $0(-8,10)$ & $1.68 \pm 3.28$ & $2(-3,13)$ & $0.002^{\mu}$ \\
\hline
\end{tabular}

$\Delta$ gain: Post-treatment-pre-treatment measurement

$\S_{t}$ test in independent groups

" Mann-Whitney $U$ test

Group 1 patients receiving physical therapy and exercises for treatment

Group 2 patients receiving physical therapy, balneotherapy, and exercises for treatment

VAS Visual Analogue Scale

QuickDASH Quick Disabilities of the Arm, Shoulder and Hand

SF36 Short Form-36

There are many studies on the use of balneotherapy in various musculoskeletal diseases in the literature (Odabaş1 et al. 2002; Şen et al. 2007; Herisson et al. 2014). Although still not among the recommended treatment methods in some international treatment guidelines and meta-analyses, it is one of the recommendations of the Turkish League Against Rheumatism (TLAR) for the treatment of knee osteoarthritis and ankylosing spondylitis (Bodur et al. 2011; Tuncer et al. 2012). Also, among the non-pharmacologic treatment recommendations of ankylosing spondylitis in the Assessment of Spondyloarthritis International Society (ASAS)/European League Against Rheumatism (EULAR) prepared by van den Berg (2012), balneotherapy is recommended in combination with other non-pharmacologic treatments or alone in addition to pharmacologic treatment.

The thermal, chemical and anti-inflammatory effects of balneotherapy have been stated in numerous studies in the literature (Gálvez et al. 2018; Morer et al. 2017; Cozzi et al.
2018). Also, its benefits on pain and joint stiffness at the cellular-molecular level have been shown. (Kurt et al. 2016; Koczy et al. 2019; Fioravanti et al. 2011), Balneotherapy provides analgesic effects by preventing the stimulation of nociceptive receptors, reducing pain transmission through the gate control theory of pain stimulating thick nerve-fibers, removing oxygen radicals, and increasing beta-endorphin levels in particular (Yurtkuran et al. 1993; Koczy et al. 2019; Tishler et al. 2004; Bender et al. 2005; Hizmetli and Hayta 2011). Again in the literature, it has been shown that balneotherapy treatments decrease inflammation and, ultimately, pain by increasing antiinflammatory cytokines (Shehata et al. 2006). In our study, we think that the greater improvement in active joint ROM, pain, and shoulder functions of the group receiving balneotherapy may be related to the pathophysiological mechanisms demonstrated in the studies mentioned above. However, reallife data and studies on patients with shoulder pain are less than the other pain syndrome groups (Karagulle et al. 2017). 
There was statistically significant increase in handgrip strength measurements with the Jamar hand dynamometer in the post-treatment results of group 2 compared with pretreatment $(p<0.05)$. In the analysis of delta gains, the gain in the group receiving balneotherapy was also significantly higher. The pain and inflammation reduction and thermal effect mechanisms of balneotherapy have been investigated in many studies in the literature. In response to heat, the elasticity of tissues containing collagen increases, muscle spasm decreases (possibly reducing pain), and joint function improves (Tishler et al. 2004; Bender et al. 2005; Shehata et al. 2006; Fioravanti et al. 2011). Handgrip strength is a clinical measurement that is aimed to be improved with decreasing pain and spasm.

There were significant improvements in sub-parameters of SF-36, except for general health perception and mental health $(p<0.05)$ in group 1 . However, in group 2 , there was a significant improvement in all parameters $(p<0.05)$. When the post-treatment changes of the two groups were compared, the well-being was higher in the group receiving balneotherapy, except for the role limitation and mental health sub-parameters due to emotional problems.

Balneotherapy has been shown to increase physical and mental quality of life, reduce anxiety and depression, as well as reduce pain and improve functions (Evcik et al. 2002; Fioravanti et al. 2012; Tefner et al. 2015). These effects are estimated to be due to adaptive modifications, particularly in autonomic and behavioral changes in regulatory systems (Bender et al. 2005). For these reasons, balneotherapy is widely used today for therapeutic purposes. In the study of Çağlar (2015), in which the additional contributions of balneotherapy to physical therapy in various musculoskeletal diseases were investigated, a higher rate of improvement was found in favor of the group that received balneotherapy in all sub-parameters of the quality of life scales. Also, similar results have been revealed concerning quality of life in balneotherapy studies with regional diseases such as knee osteoarthritis, hand osteoarthritis, chronic low back pain, and hip osteoarthritis (Guillemin et al. 1994; Horvath et al. 2012; Kesiktaș et al. 2012; Kovacs et al. 2012; Onat et al. 2014, Kovacs et al. 2016). However, different results were reported in SF-36 sub-parameters in a two-center study examining balneotherapy in chronic shoulder pain, in which the control group was given TENS and exercise (Tefner et al. 2015). There were improvements in both groups in the role limitation related to physical problems, vitality, and pain sub-parameters, but the group receiving balneotherapy had no superiority. Additionally, the role limitations due to emotional problems sub-parameter did not improve in either group.

In the abovementioned studies and in our study, most of the SF-36 sub-parameters improved with the spa treatment in general, but different results were obtained in some sub-parameters. In our study, patients undergoing balneotherapy received daily outpatient treatment due to their clinical conditions and intensity. This situation resulted in patients not being able to benefit from recreational factors that increase quality of life, such as environmental change, stress relief, lifestyle change, and rest, which are thought to contribute to the effectiveness of balneotherapy. Therefore, differences in sub-parameters of the quality of life scale (SF-36) may be related to this fact.

In some of the studies performed with diagnostic framing in which the additional contribution of balneotherapy to treatment methods was evaluated, follow-up that could provide data on long-term permanent effects was conducted. However, in our study, the data only included results of the short-term effects because many of the patients were not present in the long-term follow-up. These outcomes revealed additional contributions of balneotherapy in the early period.

In two studies, although patients with newly diagnosed shoulder pain received primary therapy, it was reported that $40-50 \%$ of patients continued to have pain even after $6-12$ months (Croft et al. 1996, Winters et al. 1999). Kujipar et al. also indicated, when shoulder pain is taken into account, $80 \%$ of the expenditures are made up of patients who do not receive good results despite conservative or surgical treatments (Kuijpers et al. 2006). Balneotherapy is a cost-effective treatment and helps to reduce both the loss of labor force and treatment costs (Van Tubergen et al. 2002). When used together with routine physical therapy methods, balneotherapy can contribute to the treatment of musculoskeletal diseases, especially in early stages, to prevent the symptoms from becoming chronic.

As in our study, the efficacy of balneotherapy should be investigated in specific pathologies, with more extensive series and longer follow-up. Our study is important in terms of being the first on a specific pathology among studies investigating the effectiveness of balneotherapy in shoulder diseases. We believe that this study may be a guide for further research.

Open Access This article is licensed under a Creative Commons Attribution 4.0 International License, which permits use, sharing, adaptation, distribution and reproduction in any medium or format, as long as you give appropriate credit to the original author(s) and the source, provide a link to the Creative Commons licence, and indicate if changes were made. The images or other third party material in this article are included in the article's Creative Commons licence, unless indicated otherwise in a credit line to the material. If material is not included in the article's Creative Commons licence and your intended use is not permitted by statutory regulation or exceeds the permitted use, you will need to obtain permission directly from the copyright holder. To view a copy of this licence, visit http://creativecommons.org/licenses/by/4.0/.

\section{References}

Bender T, Karagulle Z, Balint GP, Gutenbrunner C, Balint PV, Sukenik S (2005) Hydrotherapy, balneotherapy, and spa treatment in pain management. Rheumatol Int. 25(3):220-224 
Bodur H, Sivas F, Yilmaz Ö, Özgöçmen S, Günaydin R, Taciser K et al (2011) Turkish league against rheumatism national recommendations for the management of ankylosing spondylitis. Turk J Rheumatol. 26(3):173-186

Branco M, Rego NN, Silva PH, Archanjo IE, Ribeiro MC, Trevisani VF (2016) Bath thermal waters in the treatment of knee osteoarthritis: a randomized controlled clinical trial. Eur J Phys Rehabil Med. 52(4): 422-430

Burbank KM, Stevenson JH, Czarnecki GR, Dorfman J (2008) Chronic shoulder pain: part I. Evaluation and diagnosis. Am Fam Phys 77(4): 453-460

Çağlar H (2015) Kas iskelet sistemi hastalıklarında fizik tedavi ve balneoterapinin erken dönem depresyon, anksiyete, yaşam kalitesi ve ağrı skorlarına etkinliğinin değerlendirilmesi [Uzmanlık Tezi]. Abant İzzet Baysal Üniversitesi, Bolu

Çaliș M, Akgün K, Birtane M, Karacan I, Caliș H, Tüzün F (2000) Diagnostic values of clinical diagnostic tests in subacromial impingement syndrome. Ann Rheum Dis. 59(1):44-47

Chary-Valckenhaere I, Loeuille D, Kohler F, Pallure L, Escudier P, Jacque M, Couval M, Tamisier JN, Baraji A, Roques CF, Boulange M, Gay G (2012) Spa therapy in the treatment of chronic shoulder pain due to rotater cuff tendinopathy: Rotatherm, a large randomized multicentre trial. Ann Phys Rehabil Med. 55(S1):e352

Cohen J (2013) Statistical power analysis for the behavioral sciences. Routledge

Cools AM, Cambier D, Witvrouw EE (2008) Screening the athlete's shoulder for impingement symptoms: a clinical reasoning algorithm for early detection of shoulder pathology. Br J Sports Med. 42(8): 628-635. https://doi.org/10.1136/bjsm.2008.048074

Cozzi F, Ciprian L, Carrara M, Galozzi P, Zanatta E, Scanu A, Sfriso P, Punzi L (2018) Balneotherapy in chronic inflammatory rheumatic diseases-a narrative review. Int J Biometeorol. 62(12):2065-2071. https://doi.org/10.1007/s00484-018-1618-z

Croft P, Pope D, Silman A (1996) The clinical course of shoulder pain: prospective cohort study in primary care. BMJ. 313:601-602

Düger T, Yakut E, Öksüz Ç, Yörükan S, Bilgütay B, Ayhan Ç (2006) Kol, omuz, el sorunları (disabilities of the arm, shoulder and handDASH) anketi Türkçe uyarlamasının güvenilirliği ve geçerliliğii. FizyoterRehabil 17:99-107

Evcik D, Kizilay B, Gökçen E (2002) The effects of balneotherapy on fibromyalgia patients. Rheumatol Int. 22(2):56-59. https://doi.org/ 10.1007/s00296-002-0189-8

Filiz MB, Çakır T (2014) Omuz Ağrıları Tedavisinde Konservatif Yaklașım. Turk Klin J Phys Med Rehabil Spec Top 7(2):52-59

Fioravanti A, Cantarini L, Guidelli GM, Galeazzi M (2011) Mechanisms of action of spa therapies in rheumatic diseases: what scientific evidence is there? Rheumatol Int. 31(1):1-8

Fioravanti A, Giannitti C, Bellisai B, Iacoponi F, Galeazzi M (2012) Efficacy of balneotherapy on pain, function and quality of life in patients with osteoarthritis of the knee. Int J Biometeorol. 56(4): 583-590. https://doi.org/10.1007/s00484-011-0447-0

Fioravanti A, Tenti S, Giannitti C, Fortunati NA, Galeazzi M (2014) Short- and long-term effects of mud-bath treatment on hand osteoarthritis: a randomized clinical trial. Int J Biometeorol. 58(1):79-86

Forestier R, Erol-Forestier FB, Francon A (2017) Current role for spa therapy in rheumatology. Joint Bone Spine. 84(1):9-13

Gálvez I, Torres-Piles S, Ortega-Rincón E (2018) Balneotherapy, immune system, and stress response: a hormetic strategy? Int J Mol Sci 19(6):1687. Published 2018 Jun 6. https://doi.org/10.3390/ ijms 19061687

Guillemin F, Constant F, Collin JF, Boulange M (1994) Short and longterm effect of spa therapy in chronic low back pain. Br J Rheumatol. 33(2):148-151

Herisson C, Tavares I, Thomas E, Françon A, Forestier R, Roques C (2014) Balneotherapy for rheumatic conditions-evidence based recommendations. Ann Phys Rehabil Med (57)e160
Hizmetli S, Hayta E (2011) Kaplica Tedavisi. Turk Klin J PM\&R-Spec Top. 4(3):29-34

Hong CZ (2011) Muscle pain syndromes. In: Braddom RL (ed) Physical medicine and rehabilitation, 4th edn. Elsevier Saunders, Philadelphia, pp 971-1001

Horvath K, Kulisch A, Nemeth A, Bender T (2012) Evaluation of the effect of balneotherapy in patients with osteoarthritis of the hands: a randomized controlled single-blind follow-up study. Clin Rehabil. 26(5):431-441

Kang M, Ragan BG, Park JH (2008) Issues in outcomes research: an overview of randomization techniques for clinical trials. J Athl Train. 43(2):215-221

Karagulle M, Kardes S, Karagulle MZ (2017) Real-life effectiveness of spa therapy in rheumatic and musculoskeletal diseases: a retrospective study of 819 patients. Int J Biometeorol. 61(11):1945-1956

Karel Y, Scholten-Peeters GGM, Thoomes-de Graaf M, Duijn E, van Broekhoven JB, Koes BW et al (2017) Physiotherapy for patients with shoulder pain in primary care: a descriptive study of diagnosticand therapeutic management. Physiotherapy. 103(4):369-378

Kesiktas N, Karakas S, Gun K, Gun N, Murat S, Uludag M (2012) Balneotherapy for chronic low back pain: a randomized, controlled study. Rheumatol Int. 32(10):3193-3199

Kocyigit H, Aydemir O, Fisek G, Olmez N, Memis A (1999) Validity and reliability of Turkish version of Short form 36: A study of a patients with romatoid disorder. J Drug Ther (in Turkish) 12:102-106

Koczy B, Stołtny T, Pasek J, Leksowska-Pawliczek M, Czech S, Ostałowska A, Kasperczyk S, Białkowska M, Cieślar G (2019) Evaluation of $\beta$-endorphin concentration, mood, and pain intensity in men with idiopathic hip osteoarthritis treated with variable magnetic field. Medicine (Baltimore). 98(30):e16431. https://doi.org/10. 1097/MD.0000000000016431

Kovacs C, Bozsik A, Pecze M, Borbely I, Fogarasi A, Kovacs L et al (2016) Effects of sulfur bath on hip osteoarthritis: a randomized, controlled, single-blind, follow-up trial: a pilot study. Int J Biometeorol. 60(11):1675-1680

Kovacs C, Pecze M, Tihanyi A, Kovacs L, Balogh S, Bender T (2012) The effect of sulphurous water in patients with osteoarthritis of hand. Double-blind, randomized, controlled follow-up study. Clin Rheumatol 31(10):1437-1442

Kuijpers T, van Tulder MW, van der Heijden GJ, Bouter LM, van der Windt DA (2006) Costs of shoulder pain in primary care consulters: a prospective cohort study in The Netherlands. BMC Musculoskelet Disord. 7:83

Kurt EE, Erdem HR, Tuncay F (2016) Kronik İnflamatuar Romatizmal Hastalıklarda Kaplıca Tedavisi. J Phys Med Rehabil Sci

Luime JJ, Koes BW, Hendriksen IJM, Burdorf A, Verhagen AP, Miedema HS et al (2009) Prevalence and incidence of shoulder pain in the general population; a systematic review. Scand J Rheumatol. 33(2):73-81

Morer C, Roques CF, Françon A, Forestier R, Maraver F (2017) The role of mineral elements and other chemical compounds used in balneology: data from double-blind randomized clinical trials. Int $\mathrm{J}$ Biometeorol. 61(12):2159-2173. https://doi.org/10.1007/s00484$017-1421-2$

Nasermoaddeli A, Kagamimori S (2005) Balneotherapy in medicine: a review. Environ Health Prev Med. 10(4):171-179

Odabașı E, Karagülle M, Karagülle M, Turan M, Karagülle O (2002) Comparison of two traditional spa therapy regimens in patients with knee osteoarthritis. Phys Med Rehabil Kurortmedizin 12(06):337341

Onat SS, Tasoglu O, Guneri FD, Ozisler Z, Safer VB, Ozgirgin N (2014) The effectiveness of balneotherapy in chronic low back pain. Clin Rheumatol. 33(10):1509-1515

Reilingh ML, Kuijpers T, Tanja-Harfterkamp AM, van der Windt DA (2008) Course and prognosis of shoulder symptoms in general practice. Rheumatology (Oxford). 47(5):724-730 
Roe Y, Soberg HL, Bautz-Holter E, Ostensjo S (2013) A systematic review of measures of shoulder pain and functioning using the International classification of functioning, disability, and health (ICF). BMC Musculoskelet Disord 14:73

Roques CF, Queneau P (2016) SPA therapy for pain of patients with chronic low back pain, knee osteo-arthritis and fibromyalgia. Bull Acad Natl Med 200(3):575-586 discussion 86-7

Şen U, Karagulle M, Erkorkmaz U (2010) The efficacy of balneotherapy in the patients with subacromial impingement syndrome. Türk Klin J Med Sci 30(3):906-913

Șen U, Karagülle MZ, Karagülle M (2007) The efficacy of peloidotherapy on knee osteoarthritis. Türk Romatol Derg. 22:5559

Shehata M, Schwarzmeier JD, Hilgarth M, Demirtas D, Richter D, Hubmann R et al (2006) Effect of combined spa-exercise therapy on circulating TGF-beta1 levels in patients with ankylosing spondylitis. Wien Klin Wochenschr 118(9-10):266-272

Tefner IK, Kovacs C, Gaal R, Koroknai A, Horvath R, Badruddin RM et al (2015) The effect of balneotherapy on chronic shoulder pain. A randomized, controlled, single-blind follow-up trial. A pilot study. Clin Rheumatol. 34(6):1097-1108

Tishler M, Rosenberg O, Levy O, Elias I, Amit-Vazina M (2004) The effect of balneotherapy on osteoarthritis. Is an intermittent regimen effective? Eur J Intern Med 15(2):93-96

Tuncer T, Çay HF, Kaçar C, Altan L, Atik OȘ, Aydın A (2012) Diz osteoartrit tedavisinde kanıta dayalı öneriler: Türkiye Romatizma
Araștırma ve Savaș Derneği uzlașı raporu. Turk J Rheumatol. 27(1):1-17

Van den Berg R, Baraliakos X, Braun J, van der Heijde D (2012) First update of the current evidence for the management of ankylosing spondylitis with non-pharmacological treatment and non-biologic drugs: a systematic literature review for the ASAS/EULAR management recommendations in ankylosing spondylitis. Rheumatology (Oxford) 0.51(8):1388-1396

Van Tubergen A, Boonen A, Landewé R et al (2002) Cost effectiveness of combined spa-exercise therapy in ankylosing spondylitis: a randomized controlled trial. Arthritis Rheum. 47(5):459-467. https:// doi.org/10.1002/art.10658

Vecchio P, Kavanagh R, Hazleman BL, King RH (1995) Shoulder pain in a community-based rheumatology clinic. Br J Rheumatol. 34(5): $440-442$

Winters JC, Sobel JS, Groenier KH, Arendzen JH, Meyboom-de JB (1999) The long-term course of shoulder complaints: a prospective study in general practice. Rheumatology. 38:160-163. https://doi. org/10.1093/rheumatology/38.2.160

Yurtkuran M, Yurtkuran M, Alp A, Nas K (1993) Balneotherapy on the plasma- $\beta$-endorphine (BE) level in patients with osteoarthritis. PhysMed Rehab Kuror 3(5):130-2.10

Publisher's note Springer Nature remains neutral with regard to jurisdictional claims in published maps and institutional affiliations. 